\author{
Baiba Brigmane \\ BA School of Business and Finance, Latvia
}

\title{
COMPONENTS OF THE PEDAGOGICAL WORK AT THE UNIVERSITY
}

\begin{abstract}
Competitiveness of economy and well-being of the population are increasingly dependent on an educated society, where universities and their academic staff play an important role in the learning process of students and adults - participants of courses. Therefore, the author of the article aims to find out what are the most important components of the pedagogical work, which must be emphasized in the activities carried out by the teaching staff in order to achieve ever better learning outcomes. Data of two studies carried out by the author are being analysed - evaluation provided by future entrepreneurs of their involvement in the study process during the courses and students' opinion about competences necessary for the lecturer. The author has concluded that cooperation between students and lecturers in the practical application of theoretical knowledge, its evaluation and improvement of mutual communication skills, are essential for the study process. The importance of developing competences for lifelong learning of the future society, as well as opportunities for developing competences that are to be improved in cooperation with students, who would have acquired secondary education based on new content, should be emphasized among the lecturers.
\end{abstract}

Keywords: communication, competence, cooperation, lecturer, pedagogical work.

\section{Introduction}

Future competitiveness of Latvia in the global economy depends on human resources, which in the course of a knowledge-based society development are able to adapt to a dynamically changing environment and respond to changes in the global economy. Along with a rapid development of technologies and the global economy, progressive societies turn into the societies in which knowledge and information are the main means of production. When looking from a long-term view, knowledge is more 
important for the economic competitiveness rather than the equipment, at the same time and the ability to acquire new competences that are needed throughout the life are more significant than a certain qualification. Future society is based on educated knowledge providers - the academic staff of universities - and educated consumers. Therefore, knowledge based society and economy requires large-scale and socially inclusive investments in human capital, especially in knowledge, education and research. The surrounding world demands changes also in education content, as well as in the attitude of the process participants. "Educational success is no longer primarily a reproduction of the content of knowledge, but the practical use of knowledge, applied in new situations". (Fadel, et al., 2017) A new general education competence approach in the content of the studies, developed in Latvia, is oriented towards the use of knowledge. Moreover, higher education establishments should start preparing for a new approach towards the content acquisition, promoting innovation in teaching methods and the use of new technologies. "In the $21^{\text {st }}$ century the new generation can be directly defined as the digital generation. Digital technology that provides opportunities is a part of their integral existence component. Taking into account digital generation's needs, also pedagogy needs to respond to these needs". (Baldinšs, 2017) In few years, lecturers will work with students who have acquired secondary education oriented towards the use of knowledge. Therefore, the author of the article has set an aim to find out the characteristic components of the pedagogical work that should be emphasized in the work of academic staff in their relationship with students. When analysing scientific literature and conducting students' opinion research, the following main components of pedagogical activity can be put forward: communication, self-examination, creativity, as well as organizational and methodological approach. A balanced use of these components ensures a competent and active collaboration between the knowledge user and the knowledge carrier. Based on the research data from the doctoral dissertation, competence is a skill, based on attitudes and knowledge, and used as an ability to perform and build self-experience in accordance with personal development.

In order to raise an importance of the pedagogical competence of the academic staff in higher education and to improve results of the pedagogical interaction during the study process, activities characterizing the pedagogical competence of lecturers and attesting the conformity of higher education reforms with professionalism, and a way how it would be possible to improve the quality of higher education by focusing on science and research based studies, should be identified. The world-renowned studies acknowledge that the key skills of the $21^{\text {st }}$ century are as follows: 
Collaboration, Communication, Creativity and Critical Thinking (Trilling, Fadel, 2009).

Communication is becoming a leading competence in most professions. According to the study carried out at the Harvard University in 2015 in which 25 million job advertisements were analysed, communication ranks the first in 13 occupational groups, it also ranks the second in 2 occupational groups out of 28 skills defined in 15 occupational groups (Burning-glass study, 2015). These skills are especially important for lecturers, because they should be able not only to apply this skill themselves but also to help students master and improve these skills. The concept of creativity raised in Latvia implies assessing the necessary skills and abilities of young people, emphasizing the educational system's reorientation towards developing abilities of young people to think independently, critically and creatively, as well as to cooperate and adapt.

\section{Methods and Materials}

The methodological basis of the research is grounded on theories of philosophers, psychologists and educators about human-pedagogical processes in the learning nowadays, a structurally procedural approach to educational work foreseeing a united implementation of objective and subjective work components in the learning and providing the purport of the learning (Леонтьев, 2007; Giese, 2010; Göhlich, 2007; Bruner, 1971; Кларин, 1998; Špona, 2006). The main principle of humanism is satisfying human needs and enhancing development of abilities within the learning, while the task of the practice is to actualize the components of pedagogical work necessary for lecturers, which would ensure an acquisition of reasonable research results that can be used for improvement of the study process. The article is based on the notion that "the science of pedagogy is not a fundamental science, but the theory and practice of organized learning acquisition process. Its educational, developmental and educative goals in their unity are oriented towards the preparation of children / pupils / students for life and activities in the cultural environment". (Žogla, 2018)

The research data from the doctoral dissertation, defended by the author, about the learning process of future entrepreneurs, where the opinion of 209 respondents was recorded before and after the studies, has been analysed in the article (Brigmane, 2014). Out of all the students who participated in the State Support Program for Young Entrepreneurs the "Starter Program", these people volunteered to analyse their self-experience in the learning process. Respondents included: 112 (54\%) women and $97(46 \%)$ men covering all regions of Latvia, 3\% with a primary education, 
$60(29 \%)$ - with secondary education, with a bachelor's degree 79 (38\%) and a master's degree $-62(30 \%)$, age till 25 were $27(13 \%)$, age between 26 and $45-135(65 \%)$, over 45 years $-47(22 \%)$ of course students. The survey was conducted both before and after the completion of studies in accordance with the author's developed self-assessment criteria.

The methods of mathematical statistics were used to test the reliability of the research results. Since in this specific case, the same audience ( $n=209$ ) was repeatedly tested, the Wilcoxon Signed Ranks Test and the Spearmen's Correlation Coefficient matrix were used to process the data obtained in the survey. Apart from that the results of a study carried out by the author in 2017 among 167 students studying at the BA School of Business and Finance were taken into account to identify the competences necessary for lecturers.

In the research participated $70(42 \%)$ men and 97 (58\%) women, age between 20 and 23, everyone with a secondary education. Firstly, students responded to the questions about the importance of pedagogical competencies and secondly, answered the open questions about the competencies necessary for the lecturer. Students ranked the proposed 5 pedagogical components by significance from 1 to 5 . When calculating and assuming the highest rated component has an index 1, the remaining values obtained the corresponding indexes (see Figure 1).

Although discussions criticising students' competence to assess the professionalism of lecturers can be found in the literature, students' learning experience, their expectations during the study process and their view regarding lecturer's didactical performance are useful resources for studying professional activities of lecturers and identifying better practice in the quality culture of higher education institutions (Eisenberger, et al., 2005; Schmidt, 2008).

Documents regulating activities of the universities in Latvia and Europe - European guidelines for ensuring the quality of higher education in the area of the European higher education (Standard and ..., 2015) and the Law on Higher Education (Law on..., 1996) were used in the study.

\section{Results}

Lecturers within their professional activities form daily interaction by communicating with different target groups: students, colleagues and representatives of relevant professional organizations (employers). Communication with students is a mutual intergenerational cooperation that points out the ability to collaborate, to accept different opinions, to speak with respect, to reach an agreement, to listen to, to encourage and to evaluate. Studying views of the students who study at the BA School 
of Business and Finance results indicate that communication skills are set forward as the main and priority competences (with an index 1) (see Figure 1). The most typical responses to the open question about the communication skills necessary for a lecturer are as follows: “... to adapt to different audiences; ... to collaborate with students, to listen to and support or correct a student's point of view; ... understanding a student's level of competence while reading lectures; ... to be a life experienced person sharing the former..." Skills to be advanced the most in communication with colleagues are related to creating more targeted and closer cooperation among lecturers of different universities in the interdisciplinary context of sciences and strengthening science and research-based study provision. "In communication with representatives of professional organizations (employers), knowledge should be up-dated on a regular basis. In addition to the above, the students surveyed within the study have pointed out that “... a lecturer shall have an up-to-date knowledge about the topicalities and innovations of the course; ... not only theoretical knowledge, but also a huge practice obtained working in the relevant field; ... understanding not only their own specialty, but also the related ones." Currently communication has become one of the most dynamic social phenomena, but cooperation during the study process becomes an essential principle throughout the whole education process. Therefore, a lecturer's task is to organize the academic work in such a way that students would feel as equal partners participants of the process, where intergenerational communication results in an exchange of self-experience.



Figure 1. Components of Pedagogical Work

The study reveals that the organization of lectures has been evaluated as the second (index 1.3) most important component of the pedagogical work (see Figure 1). In order to create a free and creative cooperation with the audience during the lectures, a lecturer guides students towards acquiring target oriented cooperation skills that allows doubts, mistakes, support in common searches and promotes the feeling of togetherness in 
communication. The target oriented cooperation is grounded in democratic style of performance and such means and methods of human pedagogy applied by lecturers that ensure self-realization of the audience. The cooperation manifests in an independent choice of what, how and how much a student learns in acquiring personally significant items. In the work with adults, lecturers structure the course according to the stages of the organization of cooperation: psychological preparation, which includes setting the purpose; practical preparation, which includes coordination of the learning resources for acquiring the content and achieving a goal; implementation of the activity, which includes content acquisition and assessment of the work process and its results, as well as self-assessment. When studying the organization of the learning process of future entrepreneurs and formation of their self-experience, it turned out that only half of the audience felt like having a dialogue with an opportunity to express their opinion, but 63 percent of respondents stressed that they felt confident of having a possibility to ask a question to the lecturer (see Figure 2).

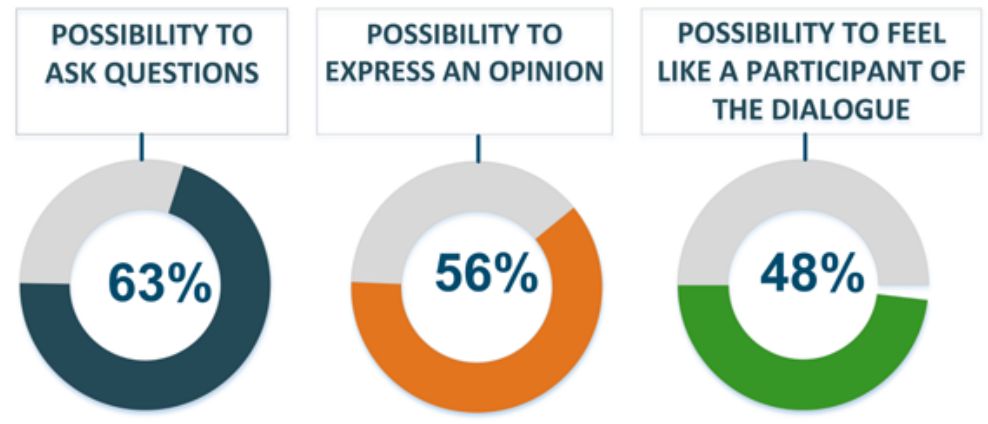

Figure 2. Cooperation with Future Entrepreneurs during the Studies

Another component is creativity that is ranked as the third (index 2.2) most significant element (see Figure 1). Creativity in education focuses on interdisciplinary cooperation and development of skills; imagination that is developing an individuality; creative thinking and talent-improving process of the learning. In creative thinking, both the lecturer and also the student shall adopt a new view of things, situations and processes, as well as various new ideas and their solutions, formation of which is not a result of template thinking. The main components of such learning are experience and dialogue. Paulo Freire has evaluated this complicated pedagogical activity and he claims that the normal role of people in the world is not a passive one. They are participants of the creative dimension, what results in the ability to adapt to the reality, make choices and transform the reality (Freire, 1985). 
By implementing study plans, programs and didactical methods, which in turn activates self-directed and independent study and research skills, a purposeful transition from lecturer-led studies to a student-centred selfeducation process is achieved. In the above mentioned process, a lecturer and his pedagogical competence is an important component of the structure.

The study shows that self-examination is rated as the fourth competence (index 2.5) in the pedagogical work (see Figure 1). The lecturer shall continuously follow his/ her growth by assessing the relevance of the use of self-experience and competence to the situation. The inclusion of new experiences in the content of the previous experience requires a cognitive process - learning. Therefore, in the pedagogical work, both the students and the adults have certain cooperation difficulties in the organization of process of acquiring new competences and self-experience. Previous experience of each and every person, as an inherent value of the learning process, resists new experience, because it is difficult to give up the old and the habitual that possesses a personal value. The experience-oriented theory by Michael Göhlich views interaction between the activity and the passivity. Difference between the activity and the passivity is hidden in "relevant prioritization" (Göhlich, 2007, 191).

The methodological component (index 2.7) is essential in the pedagogical process, as one of the most difficult issues in organizing the contemporary educational process is the question of how to achieve a situation that every participant of the educational process is aware of his/ her learning goals (see Figure 1). Through the method of cooperation, goals of a pedagogue and each participant of the process approximates: a pedagogue clearly understands what and how should be learnt and which methods should be used, and offers options, but participants of the process choose and coordinate the content of the learning process and the organization of its acquisition.

The study on identifying the learning needs of future entrepreneurs showed that before the studies, majority of students - 45 per cent, considered the group work method as the most effective, but 39 per cent found the practice application as such. After the studies, 68 per cent of the audience recognized the practice application as the most productive method, 23 per cent gave priority to the group work method, and 9 per cent - to the monologue method. David Kolb considers that the learning process of a person is based on the experience and skills to gain a new experience, to reflect it, to conceptualize and to experiment (Kolb, 1974). Human-oriented science of pedagogy focuses towards a human being as the highest value; the advancement processes of his/ her natural and social development; possibilities and preconditions for his/ her free self-development. 


\section{Discussion and conclusions}

The above mentioned can only be implemented by the academic staff that is professionally trained and academically educated according to modern competences. However, also the higher education institutions should actively participate in the improvement of professional qualification of lecturers and implementation of requirements of regulations. Article 5, p. $2^{1}$ of the Law on Higher Education stipulates the tasks of the universities: The universities... establishes an internal order and mechanisms to provide qualification level of the academic personnel and its work quality; Article 26, p. 5 - the personnel of the university, its rights and duties: the leadership of the university shall take care of the personnel's work conditions and provide a possibility to raise qualification and retrain. (Law on ..., 1996). In p. 1.5, the European guidelines for quality assurance in the area of the European higher education state that institutions of higher education shall provide competence of their own teaching staff. The recruitment of lecturers shall be organized fairly and openly (Standarts and ..., 2015). As Ausma Špona indicates, every human being is unique and unrepeatable both in terms of a genetic nature and the way of life (Špona, 2006).

Studying the components of the professional pedagogic work of the university's teaching staff allows to conclude:

- Motivation of the personality, meaningful learning, self-analysis and self-assessment are the concepts of human pedagogy expressing respect towards human autonomy in the teaching process that is a precondition for cooperation between lecturers and students.

- In academic studies, the procedural actions shall be actualized: problem solving; reflexive, critical and creative thinking; searching for the personal significance; the use of a newly acquired experience. These findings were particularly applied to the study on the selection of adult learning content and forms, and organization of its process.

- Creative learning that features the transition from lecturer-led studies to a student-centred self-education process, activating selfdirected and independent learning and research skills during life, becomes more and more topical. As a result, learning process that nourishes talents and aims towards an interdisciplinary cooperation and development of skills, as well as an individuality-developing imagination and creative thinking, is being formed.

- Lecturers shall form a structure of the lecture according to the stages of organization of the cooperation: psychological preparation, which includes setting goals; practical preparation, which includes the coordination of learning resources for the acquisition of content 
and the achievement of the goal; implementation of the activity, which includes content acquisition, improvement of self-experience, assessment of the work process and its results; and self-assessment.

- Analysing the scientific literature and conducting the study of students' opinions, communicative, organizational, self-examination, methodological and creative components should be considered as the main in the pedagogical work. Advancement of communication skills is especially important for the lecturers, as they have to be able not only to use the former, but also help students to master and improve them.

\section{References}

Augstskolu likums (Law on Higher Education) (1996). Latvijas Vēstnesis, 179(462), 17.11.1995.; Ziñotājs, 1, 11.01.1996.

Baldiņš, A. (2017). E-Pedagoǵijas satura pilnveide. Humanitārās un sociālās zinātnes (Improvement of E-Pedagogical. Content. Humanities and Social Sciences), 27, 41.-50. lpp.

Brigmane, B. (2014). Pieaugušo pašpieredzes veidošanās mācǐšanās procesāa (Formation of adults self-experience through the process of learning). Riga: RPIVA.

Bruner, J. S. (1971). Process of education reconsidered. Phi Delta Kappan, 53, 18-21.

Burning - glass study (2015). The Human Factor: The Hard Time Employers Have. Finding Soft Skills, Burning Glass Technologies. Retrieved from http://burning-glass.com/ wp-content/uploads/Human_Factor_Baseline_Skills_FINAL.pdf.

Clarin, M. (1998). Innovacii v mirovoj pedagogike (Innovations in world pedagogy). Moscow-Riga. Pedagogical center "Experiment".

Eisenberger, K.; \& Kramer, J. W. (2005). Möglichkeiten und Grenzen der Lehrevalution an einer Hochschule. In: Kramer, J. W. (Hrsg.) Hochschulen im Spannungsfeld zwischen Lehre und Forschung (S. 39-74). München und Mering: Rainer Kampp Verlag.

Fadels, Č., Bialika, M., Trilings, B. (2017). Četru dimensiju izglitỉba. Skolēnu panākumiem nepieciešamās kompetences (Four-Dimensional Education: The Competencies Learners Need to Succeed). Lielvārde: izglìtības uzñēmums "Lielvārds".

Freire, P. (1985). The politics of education: Culture, power and liberation. South Hadley: Mass Bergin \& Garvey, 209 p.

Giese, M. (2010). Der Erfahrungsbegriff in der Didaktik - eine semiotische Analyse. Zeitschrift für Pädagogik, D 7484, Jan./Feb. 2010.

Göhlich, M. (2007). Aus Erfahrung lerner. In: M. Göhlich, C. Wulf, J. Zirfas (Ed.), Pädagogische Theorien des Lernens (S. 191-202). Weinheim und Basel: Beltz.

Kolb, D. A., Rubin, I. M., McIntyre, J. M. (1974). Organizational psychology: an experiential approach (2nd ed.). Englewood Cliffs, NJ: Prentice-Hall.

Leontjev, D. A. (2007). Psihologija smysla (Psychology of meaning). Moscow: Smisl.

Schmidt, B. (2008). Qualität der Lehre an Hochschulen. Zeitschrift für Pädagogik. Weinheim und Basel: Beltz Verlag. 
Špona, A. (2006). Audzināšanas process teorijā un praksēe (The process of upbringing in theory and practice). Rīga: RaKa.

Standards and Guidelines for Quality Assurance in the European Higher Education Area (ESG 2015). Retrieved from http://www.enqa.eu/wp-content/uploads/2015/11/ESG_ 2015.pdf.

Trilling, B. and Fadel, C. (2009) 21st Century Skills. San Francisco, CA: Jossey-Bass.

Žogla, I. (2018.) Science of Pedagogy and Educational Sciences. Latvijas Universitātes

Raksti, 816, 87-109. Retrieved from https://doi.org/10.22364/ped.luraksti.816.07. 